\title{
ALPHEOPSIS CORTESIANA, A NEW SNAPPING SHRIMP FROM THE GULF OF CALIFORNIA
}

\author{
Mary K. Wicksten and Michel E. Hendrickx
}

\begin{abstract}
A new species of subtidal snapping shrimp has been dredged off Sinaloa, Mexico. The species, most closely resembling Alpheopsis harperi of the Gulf of Mexico, has a large chela with an arched dactyl. There are no grooves on the large chela. A key to the eastern Pacific species of Alpheopsis is provided.
\end{abstract}

Species of Alpheopsis, like other members of the family Alpheidae, commonly are called snapping shrimps. In the eastern $\mathrm{Pa}$ cific, species of Alpheopsis often are infaunal inhabitants of offshore bottoms. Most records come from material taken in box cores, grabs, and dredges.

During benthic studies by the R.V. El Puma in the Gulf of California, a new species of snapping shrimp was discovered, and is described herein. The drawings are by Debbie Meier, Texas A\&M University.

\section{Alpheopsis cortesiana, new species} Fig. 1

Description. - Rostrum short, acute, carinate, exceeding ocular spines, falling far short of distal end of first article of antennular peduncle. Orbital teeth acute. Eyes covered in dorsal view, covered or partly exposed in lateral view. Pterygostomial angle of carapace rounded.

Antennular peduncle long, second article longest. Stylocerite long and acute, reaching beyond end of first antennular article. Scaphocerite reaching as far as or falling slightly short of distal end of antennular peduncle, its lateral spine overreaching blade. Carpocerite longer than scaphocerite and antennular peduncle. Basicerite with small lateral tooth.

Large cheliped with chela having palm $1.5 \times$ as long as broad. Margins of chela without grooves or notches. Fixed finger with
7 large teeth and 5-7 denticles distal thereto. Dactyl with 5-6 weak teeth. Dactyl lamellate, upper margin strongly convex. Carpus short, cup-shaped. Merus slender, $3 \times$ as long as broad, with 2-3 spines on superior margin. Ischium short. Small chela missing in both specimens.

Second leg with ratio of carpal articles 10 : $4: 4: 4: 4$.

Third leg slender. Dactyl sickle-shaped, $7 \times$ as long as wide. Propodus $2 \times$ length of dactyl, slender, without spines but bearing long setae. Carpus $0.8 \times$ length of propodus, merus $1.5 \times$ length of carpus. Ischium $0.5 \times$ merus, without spines. Fourth and fifth legs similar to third.

Telson more than $2 \times$ long as wide, wider at proximal end than at distal; with 2 pair dorsolateral spines and pair of spines on distal margin. (Constriction at end of anterior third, as shown in illustration, probably due to damage to specimen.) Uropods longer than telson.

Holotype. - Female, total length $19.7 \mathrm{~mm}$. Off Río Fuerte, Sinaloa, Mexico $\left(25^{\circ} 48^{\prime} \mathrm{N}\right.$, $\left.109^{\circ} 34^{\prime} \mathrm{W}\right), 90 \mathrm{~m}$, mud, 12 May 1982, Van Veen grab, R.V. El Puma, CORTES cruise 1, Allan Hancock Foundation (University of Southern California) type number 82-2.

Paratype. - Female, total length $9.0 \mathrm{~mm}$. Off Mazatlán, Sinaloa, 20 m, compact mud, 13 March 1981, in oyster dredge, R.V. El Puma, Estación Mazatlán catalog number EMU-2096. 

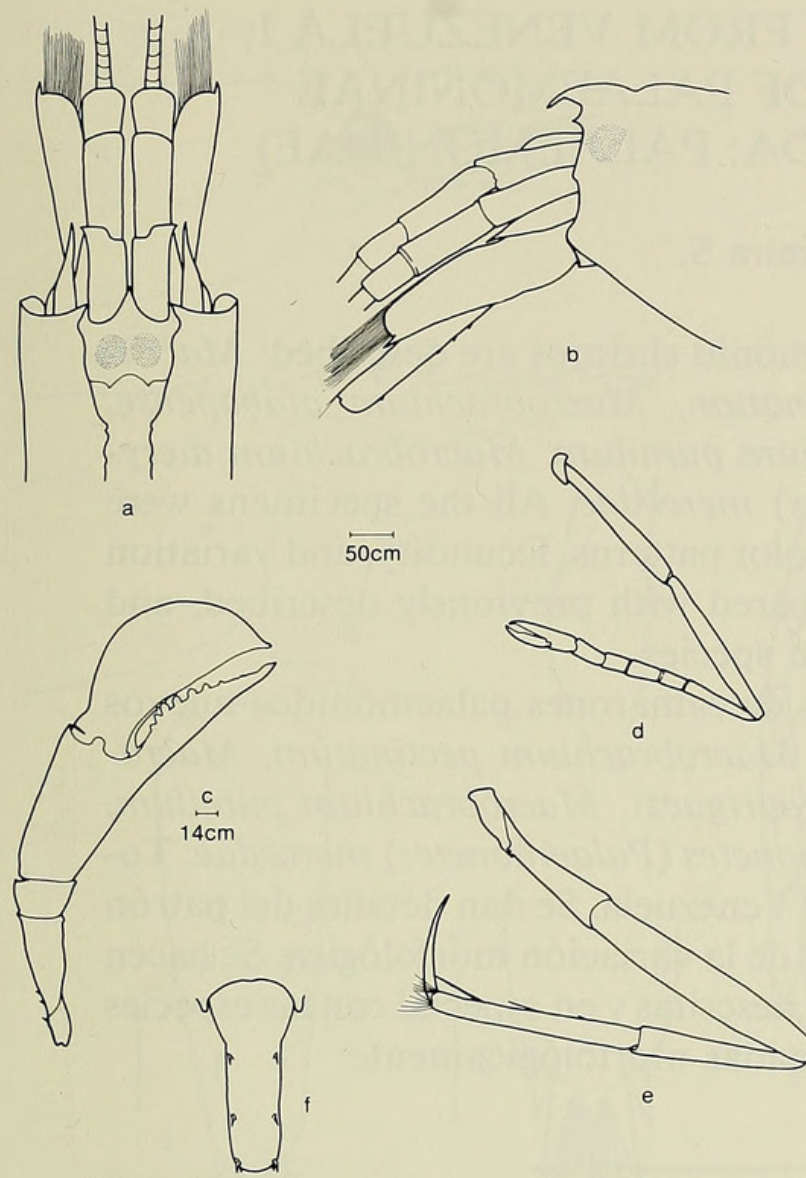

Fig. 1. Alpheopsis cortesiana, holotype female. a, Frontal region in dorsal view; b, Frontal region in side view; c, Major cheliped; d, Second pereopod; e, Third pereopod; f, Telson.

Etymology. - The specific epithet refers to the Sea of Cortés, from which the species was collected.

Discussion. - Alpheopsis cortesiana most closely resembles $A$. harperi Wicksten, 1984, from the Gulf of Mexico. Both are offshore infaunal species with large chelae lacking grooves but having dactyls with convex margins. Alpheopsis harperi, however, lacks teeth on the fingers of the chela. It has spinules on the propodus of the third leg. The second article of the carpus of the second leg is longer than in $A$. cortesiana, and the dactyl of the third leg is shorter.

There are no published reports of other species of Alpheopsis in the Gulf of California or off the coast of Sinaloa. However, a single ovigerous female of a different species, resembling $A$. aequalis Coutière, was collected at Isla Candelero, Sonora (6 July 1983, $10 \mathrm{~m}$, commensal with zooanthid, Alex Kerstitch, collector, Allan Hancock Foundation collections). This specimen agrees with the description of $A$. aequalis given by Banner and Banner (1973:342) except that the blade of the scaphocerite tapers to a point instead of having a broadly rounded margin. More specimens are needed before the species can be formally described.

Key to the Species of Alpheopsis in the Eastern Pacific

1. Anterior region of carapace with rostrum and orbital teeth ....... 2

- Anterior region of carapace with rostrum only, no orbital teeth ....

2. Large chela with longitudinal groove. (Southern-central California, U.S.A.)

Alpheopsis equidactylus (Lockington)

- Large chela without longitudinal groove. (Off Sinaloa, Mexico) ....

Alpheopsis cortesiana, new species

3. Large chela with notch on dorsal surface. (Chile-Peru) ...........

Alpheopsis chilensis Coutière

- Large chela without notch on dorsal surface. (Off Sonora, Mexico) ....

....Alpheopsis cf. A. aequalis Coutière

\section{Literature Cited}

Banner, D. M., and A. H. Banner. 1973. The alpheid shrimp of Australia. Part I: The lower genera. Records of the Australian Museum 28(15):291382.

Wicksten, M. K. 1984. Alpheopsis harperi (Decapoda: Alpheidae): A new species of snapping shrimp from Texas. - Northeast Gulf Science 7(1):97100 .

(MKW) Department of Biology, Texas A\&M University, College Station, Texas 77842; (MEH) Estación Mazatlán del Instituto de Ciencias del Mar y Limnología, Apartado Postal 811, Mazatlán, Sinaloa 82000, México. 


\section{$2 \mathrm{BHL}$ Biodiversity Heritage Library}

Wicksten, Mary K. and Hendrickx, Michel E. 1986. "Alpheopsis cortesiana, A New Snapping Shrimp From The Gulf Of California." Proceedings of the Biological Society of Washington 99, 196-197.

View This Item Online: https://www.biodiversitylibrary.org/item/107581

Permalink: https://www.biodiversitylibrary.org/partpdf/45435

\section{Holding Institution}

Smithsonian Libraries

\section{Sponsored by}

Biodiversity Heritage Library

\section{Copyright \& Reuse}

Copyright Status: In copyright. Digitized with the permission of the rights holder.

Rights Holder: Biological Society of Washington

License: http://creativecommons.org/licenses/by-nc-sa/3.0/

Rights: https://biodiversitylibrary.org/permissions

This document was created from content at the Biodiversity Heritage Library, the world's largest open access digital library for biodiversity literature and archives. Visit BHL at https://www.biodiversitylibrary.org. 